\title{
Physiological characteristics in seeds of the common bean under multicollinearity and conditions of salinity ${ }^{1}$
}

\author{
Características fisiológicas de sementes de feijão sob multicolinearidade em \\ condições de salinidade
}

\author{
José Henrique Soler Guilhen², Tiago de Souza Marçal'², Rafael Fonsêca Zanotti, José Carlos Lopes ${ }^{4}$ e Adésio \\ Ferreira $^{4 *}$
}

\begin{abstract}
The objective of this work was evaluate multicollinearity effect and discard the variables which are based on multicollinearity reduction in diversity analysis of common bean genotypes, related to seeds physiological quality, in different salinity levels in germination substrate. The common bean seed germination test for six cultivars and seven landrace genotypes was performed in paper rolls (germitest), imbibed in $\mathrm{NaCl}$ solutions on the osmotic potentials of $0.0 ;-0.3$ and 0.6 MPa, maintained in germinated Mangelsdorff type at temperature of $25{ }^{\circ} \mathrm{C}$, on constant light. The experimental design was completely randomized in factorial arrangement $13 \times 3$ (genotype $\mathrm{x}$ osmotic potential), with four replications with 25 seeds, totaling 100 seeds per treatment. The carried out evaluations were: weight of a thousand seeds, germination mean time, primary root protrusion in five and nine days after seeding, normal seedling percentage, hypocotyl and primary root length and dry matter from aerial part and roots. The multicollinearity diagnosis was carried out on the phenotypic correlation matrix and the characteristic discard was preceded through the canonical variable technique. To evaluate the multicollinearity effect, the Tocher cluster method was used before and after the variables discard. The proposed discard methodology of variables is efficient on the multicollinearity reduction and the number of discarded physiological quality descriptors is higher on the potentials of -0.3 and $-0.6 \mathrm{MPa}$, under salt stress conditions, need to be discarded three characteristics and in the absence of stress only two discarded, to became a weak condition of multicollinearity to follow with the cluster analysis. The common bean genotypes clusters are different on the severe and weak multicollinearity only under salt stress condition.
\end{abstract}

Key words: Phaseolus vulgaris. Salt stress. Canonical variable.

RESUMO - Objetivou-se neste trabalho avaliar o efeito da multicolinearidade e descartar variáveis baseadas na redução da multicolinearidade em análise de diversidade de genótipos de feijão, em relação à qualidade fisiológica de sementes, em diferentes níveis de salinidade em substrato de germinação. O teste de germinação de sementes do feijoeiro para seis cultivares e sete genótipos crioulos foi realizado em rolos de papel toalha, tipo germitest, embebidos em soluções de $\mathrm{NaCl}$, nos potenciais osmóticos de 0,0; - 0,3 e -0,6 MPa, mantidos em germinador tipo Mangelsdorff com temperatura de $25^{\circ} \mathrm{C}$ e luz constantes. O delineamento utilizado foi inteiramente ao acaso em arranjo fatorial $13 \times 3$ (genótipos x potenciais osmóticos), com quatro repetições de 25 sementes, totalizando 100 sementes por tratamento. Realizou-se o diagnóstico de multicolinearidade na matriz de correlação fenotípica e procedeu-se o descarte de variáveis, utilizando-se a técnica de variável canônica. Para avaliar o efeito da multicolinearidade, utilizou-se o método de agrupamento Tocher, antes e após o descarte das variáveis. A metodologia de descarte de variáveis proposta é eficiente na redução da multicolinearidade e o número de descritores de qualidade fisiológica descartados é maior nos potencias de -0,3 e -0,6 MPa. Sob condições de estresse salino necessita-se descartar três características e na ausência de estresse, apenas duas características descartadas satisfazem a condição de multicolinearidade fraca para seguir com as análises de agrupamento. Os agrupamentos dos genótipos de feijoeiro comum são alterados em condições de multicolinearidade severa e fraca, apenas na condição de estresse salino.

Palavras-chave: Phaseolus vulgaris. Estresse salino. Variável canônica.

DOI: $10.5935 / 1806-6690.20160015$

* Autor para correspondência

'Recebido para publicação em 14/08/2014, aprovado em 23/09/2015

Parte de Tese do terceiro autor apresentada ao Programa de Pós-Graduação em Produção Vegetal da Universidade Federal do Espírito Santo

${ }^{2}$ Programa de Pós-Graduação em Genética e Melhoramento, Centro de Ciências Agrárias, Alto Universitário, Universidade Federal do Espírito

Santo s/nº, Guararema, Alegre-ES, 29.500-000,jhguilhen@gmail.com; tiagosmaragronomia@gmail.com

${ }^{3}$ Programa de Pós-Graduação em Produção Vegetal, Centro de Ciências Agrárias, Alto Universitário, Universidade Federal do Espírito Santo, s/nº Guararema , Alegre-ES, 29.500-000,rfzanotti@gmail.com

${ }^{4}$ Centro de Ciências Agrárias, Alto Universitário, Universidade Federal do Espírito Santo, s/nº, Guararema, Alegre-ES, 29.500-000, jcufes@ bol.com.br; adesioferreira@gmail.com 


\section{INTRODUCTION}

The common bean (Phaseolus vulgaris L.) is a legume of the Fabaceae family, whose grain is much appreciated, being an important source of calories, proteins, carbohydrates (HADŽIĆ et al., 2013; PLANS et al., 2013), zinc (ROSA et al., 2010), iron (PEDROSA et al., 2015), and calcium (JOST et al., 2009), with a low lipid content (PEDROSA et al., 2015). In Brazil, the bean is the fifth most-produced grain crop (CONAB, 2015), and in 2012 Brazil was the world's third largest producer of the common bean, with a production of 2.94 million tonnes and a productivity of $1037.24 \mathrm{~kg} \mathrm{ha}^{-1}$ (FAO, 2013).

Salinisation reduces the productivity of various crops (ANDRÉO-SOUZA et al., 2010; MACHADO et al., 2007), including the bean (BEN-GAL et al., 2009), due to morphological changes caused by saline solutions, such as a reduction in germination (SAEIDI-SAR et al., 2013), during initial development (BOURGAULT et al., 2010) and in the vegetative growth attributed to osmotic stress; a result of the reduction in water potential of the medium and the toxic ion effect caused by the accumulation of ions in the tissues (AYDIN; KANT; TURAN, 2012; KHADRI; TEJERA; LLUCH, 2007; ROSALES et al., 2012), which modifies gene expression during salt stress (HERNÁNDEZ-LUCERO et al., 2014). However, among bean genotypes it is possible to select the most tolerant genetic materials to saline stress (BAYUELO-JIMENEZ; JASSO-PLATA; OCHOA, 2012) for use as parents in breeding programs.

One of the factors which compromise the correct interpretation of clusters is multicollinearity. This is the high correlation between the set of explanatory characteristics of an experiment, which may reduce the efficiency of the multivariate techniques that use the residual covariance matrix (CRUZ; REGAZZI, 2001). The breeder can use techniques that help reduce multicollinearity, such as discarding redundant variables, so as to decrease time and manpower in future evaluations (CRUZ; REGAZZI, 2001).

Given the above, the aim of this study was to evaluate the effect of multicollinearity and to discard variables with a view to reducing multicollinearity in the diversity analysis of bean genotypes, in relation to the physiological quality of seeds at different salinity levels in the substrate.

\section{MATERIAL AND METHODS}

The experiment was set up and carried out at the Seed Analysis Laboratory (LAS) of the Department of Plant Production at the Centre for Agricultural Sciences of the Federal University of Espirito Santo (CCA-UFES), in Alegre, in the State of Espírito Santo, Brazil (ES), in January 2013.

The seeds used in the experiment were from six cultivars of the common bean (Phaseolus vulgaris L.), provided by the Agronomic Institute of Paraná (IAPAR), in Londrina, Paraná: G1 - IPR Campos Gerais, G2 - IAPAR81, G 3 - IPR Andorinha, G4 - IPR Siriri, G5 IPR - Curió, and G6 - IPR Colibri, and seven landrace genotypes obtained from various locations: G7 - Vagem Riscada (Muqui, ES), G8 - Sangue de burro (Manhumirim, MG), G9 - Carioquinha (Tupa, SP), G10 - Rosinha (Tupa, SP), G11 - Mulatinho (Tupa, SP), G12 - Roxinho (Simonésia, MG) and G13 - Preto (São José do Mantimento, MG).

The seeds were disinfected with a $2.5 \%$ solution of sodium hypochlorite for two minutes and then in $70 \%$ alcohol for 30 seconds (modified from MESQUITA; MARINO, 2009). The germination test was carried out in a Mangelsdorff germinator, at a temperature of $25{ }^{\circ} \mathrm{C}$ and under constant light (two 40W fluorescent, special daylight lamps), with the seeds being placed in roll made up from three layers of germitest paper towel (BRASIL, 2009 ), moistened with a volume of solution equal to 2.5 times their dry weight. An osmotic potential of -0.6 MPa was considered to be moderately harmful to the vigour of the bean seeds in the germination test (COELHO et al., 2010). An osmotic potential of $0.0,-0.3$ and $-0.6 \mathrm{MPa}$ were therefore selected for the tests. For the calculation and preparation of the $\mathrm{NaCl}$ saline solutions at an osmotic potential of $0.0,-0.3$ and $-0.6 \mathrm{MPa}$, the Van't Hoff equation, as cited by Pimenta (2004), was used.

The experimental design was completely randomised, with treatments distributed in a $13 \times 3$ factorial scheme (genotypes $x$ osmotic potentials) with four replications of 25 seeds, giving a total of 100 seeds per treatment.

The characteristics to be analysed were thousand seed weight (TW) (BRASIL, 2009), mean germination time (MGT) (LABOURIAU, 1983), percentage of primary root protrusion ( $\geq 2 \mathrm{~mm}$ ) at five days after sowing (PL), and the percentage of seeds with primary root protrusion at nine days after sowing (G). The criterion of days was adapted from BRASIL (2009); the percentage of normal seedlings at nine days after sowing (NS) (BRASIL, 2009) was obtained by counting seedlings with their key structures well developed, and with more than three centimetres of root and hypocotyl.

Nine days after sowing, the length $(\mathrm{cm})$ of the hypocotyl (HL) and of the primary root (RL) of the seedlings were evaluated. Later, the shoots and roots of each of the lots were stored separately in paper bags and placed in a forced air circulation oven at $70{ }^{\circ} \mathrm{C}$ to constant 
weight (three days); weighing was by digital analytical balance $(0.0001 \mathrm{~g})$. The dry weight of the shoots (SDW) without cotyledons, and of the roots (RDW) were expressed in grams seedling ${ }^{-1}$.

The residual and phenotypic covariance matrices were estimated, and multicollinearity was diagnosed for the phenotypic correlation data, and classified as to the number of conditions $(\mathrm{NC})$, as weak $(\mathrm{NC} \leq 100)$, moderate to strong $(100<\mathrm{NC}<1000)$ and severe $(\mathrm{NC} \geq$ 1000) (MONTGOMERY; PECK, 1981). An analysis was then made of the canonical variables to discard the most important variable associated with the lowest eigenvalue (CRUZ; REGAZZI; CARNEIRO, 2012). This procedure was carried out in the form of a loop, with the first value for $\mathrm{NC}$ of less than 100 being considered as the stopping criterion.

To check the effect of multicollinearity on the variables of seed germination and initial growth of the bean seedlings, the Tocher optimisation method was used to cluster the genotypes, based on the generalised Mahalanobis distance $\left(\mathrm{D}^{2}\right)$, both before and after discarding variables. All the analyses were performed using the Genes, v.2013 software (CRUZ, 2013).

\section{RESULTS AND DISCUSSION}

The multicollinearity diagnostic carried out for the set of nine variables evaluated in the bean genotypes for each osmotic potential, gave $\mathrm{NC} \geq 1000$. After discarding one variable, the multicollinearity remained severe $(\mathrm{NC} \geq$ 1000 ) for the osmotic potential of $0.0 \mathrm{MPa}$, while for the remaining osmotic potentials $(-0.3$ and $-0.6 \mathrm{MPa})$, it went down to moderate to strong $(100<\mathrm{NC}<1000)$ (Table 1$)$.

Discarding the second variable reduced the multicollinearity to weak $(\mathrm{NC} \leq 100)$ at a potential of $0.0 \mathrm{MPa}$. However, at a potential of -0.3 and $-0.6 \mathrm{MPa}$, the multicollinearity was moderate to strong, it being necessary to discard a third variable to obtain an $\mathrm{NC} \leq 100$ (Table 1). Multicollinearity results in unsuitable clustering in the bean by preventing true expression of the degree of dissimilarity between individuals (CARGNELUTTI FILHO et al., 2009).

Analysis for the osmotic potentials showed that under conditions of salt stress it was necessary to discard three characteristics, or only two in the absence of stress, to satisfy the condition of weak multicollinearity. The greater number of discarded features under conditions of stress may be related to the close association between the variables under stress conditions. Due to the high degree of association of the variables, the effective dimension of the matrix becomes less than the total number of variables, resulting in a linear dependence between the rows of the matrix (RENCHER, 2003).

Discarding variables using the canonical variables gave a reduction in multicollinearity from 2424 to 87 , from 10448 to 61 and from 6873 to 76, for an osmotic potential of $0.0,-0.3$ and $-0.6 \mathrm{MPa}$ respectively (Table 1$)$. In the absence of stress $(0.0 \mathrm{MPa})$, the characteristic $\mathrm{G}$ was selected for disposal, as it presented a greater weighting coefficient for the least-important eigenvector in the phenotypic correlation matrix. However, discarding the $\mathrm{G}$ variable was insufficient to achieve an $\mathrm{NC} \leq 100$ (Table 2). In the second selection cycle, without the $G$ variable, PL was the variable indicated to be discarded; this had the highest coefficient of canonical weighting $(1,329)$ in absolute terms for the last canonical variable (Table 2). After discarding PL, the criterion of weak multicollinearity was achieved. The variables $G$ and PL were therefore considered redundant and increased multicollinearity at a potential of $0.0 \mathrm{MPa}$.

For a potential of $-0.3 \mathrm{MPa}$, the first characteristic suitable for discarding was PL (Table 3). A second and third cycle of discarding variables were necessary to achieve weak multicollinearity. The discarded variables were SDW and NS, based on the weights of the weighting coefficients $(0.826$ and 1.168$)$ for the last canonical variable respectively (Table 3 ). The removal of these three variables at a stress of $0.3 \mathrm{MPa}$, was sufficient to satisfy the condition of weak multicollinearity $(\mathrm{NC} \leq 100)$.

Table 1 - Multicollinearity diagnostic in relation to the number of conditions (NC), and to the number of seed and seedling variables analysed for an osmotic potential of $0.0,-0.3$ and $-0.6 \mathrm{MPa}$

\begin{tabular}{lrrr}
\hline \multirow{2}{*}{ Number of variables } & \multicolumn{3}{c}{ Osmotic potential $(\mathrm{MPa})$} \\
\cline { 2 - 4 } & 0.0 & -0.3 & -0.6 \\
\hline 9 & 2424.179 & 10448.445 & 6873.647 \\
8 & 1102.588 & 570.961 & 316.023 \\
7 & 87.783 & 251.113 & 172.965 \\
6 & ---- & 61.508 & 76.191 \\
\hline
\end{tabular}


Table 2 - Estimation of variances $(\lambda)$, accumulated variances $(\lambda \mathrm{ac})$ and standardised weighting coefficients of the canonical variables for the characteristics, thousand seed weight (TW), mean germination time (MGT), primary root protrusion at nine days (G), normal seedlings (NS), primary root protrusion on the fifth day (PL), length of hypocotyl (HL), length of root (RL), shoot dry weight (SDW) and root dry weight (RDW) in the absence of salt stress $0.0 \mathrm{MPa}$

\begin{tabular}{|c|c|c|c|c|c|c|c|c|c|c|}
\hline$\lambda$ & $\lambda_{\mathrm{ac}}$ & $\mathrm{TW}$ & MGT & $\mathrm{G}^{1}$ & NS & $\mathrm{PL}^{2}$ & $\mathrm{HL}$ & $\mathrm{RL}$ & SDW & RDW \\
\hline 96.525 & 86.232 & 1.138 & 0.230 & 0.256 & -0.216 & 0.337 & -0.180 & -0.209 & 0.253 & -0.455 \\
\hline 6.891 & 92.389 & 0.253 & -0.858 & 1.106 & -0.450 & -1.023 & -0.056 & -0.231 & -0.258 & 1.038 \\
\hline 4.517 & 96.424 & 0.038 & 0.409 & 0.435 & -0.399 & -1.171 & 1.492 & 0.332 & 0.003 & -0.457 \\
\hline 1.982 & 98.195 & 0.203 & -1.513 & 1.765 & 0.378 & -2.387 & 0.0002 & 0.745 & -0.297 & -0.762 \\
\hline 1.045 & 99.128 & -0.038 & 1.134 & -0.001 & 0.256 & 0.533 & 0.475 & 0.556 & 0.272 & -0.218 \\
\hline 0.488 & 99.565 & -0.140 & -1.384 & 1.354 & -1.516 & -0.741 & -0.004 & 0.181 & 0.708 & 0.068 \\
\hline 0.422 & 99.942 & -0.133 & -1.146 & 1.787 & 0.586 & -2.457 & 0.292 & -0.731 & 0.623 & 0.141 \\
\hline 0.054 & 99.990 & -0.135 & -0.071 & 0.851 & 0.474 & -1.646 & -0.517 & 0.435 & 0.444 & 0.040 \\
\hline 0.011 & 100.00 & -0.002 & 0.525 & -1.198 & 0.885 & 0.140 & 0.144 & 0.429 & 0.241 & -0.090 \\
\hline 95.996 & 87.356 & 1.131 & 0.406 & ---- & -0.179 & 0.615 & -0.191 & -0.208 & 0.224 & -0.456 \\
\hline 6.289 & 93.079 & 0.239 & -0.141 & ---- & -0.310 & 0.285 & -0.236 & -0.311 & -0.370 & 1.152 \\
\hline 4.442 & 97.121 & 0.055 & 0.715 & ---- & -0.404 & -0.649 & 1.464 & 0.268 & -0.072 & -0.297 \\
\hline 1.472 & 98.461 & 0.298 & -0.242 & ---- & 0.636 & -0.552 & 0.033 & 0.867 & -0.753 & -0.692 \\
\hline 1.045 & 99.412 & -0.038 & 1.133 & ---- & 0.255 & 0.532 & 0.475 & 0.556 & 0.273 & -0.218 \\
\hline 0.465 & 99.835 & 0.026 & 0.444 & ---- & 1.544 & -0.863 & 0.153 & -0.593 & -0.194 & 0.043 \\
\hline 0.145 & 99.967 & -0.006 & 0.598 & ---- & -0.102 & 0.304 & -0.541 & 0.234 & -0.296 & 0.041 \\
\hline 0.037 & 100.000 & -0.110 & 0.149 & ---- & 0.926 & -1.329 & -0.252 & 0.577 & 0.555 & -0.028 \\
\hline 87.154 & 87.081 & 1.082 & 0.416 & ---- & 0.244 & ---- & -0.056 & -0.096 & 0.237 & -0.567 \\
\hline 6.186 & 93.262 & 0.253 & -0.071 & ---- & -0.186 & ---- & -0.056 & -0.248 & -0.378 & 1.073 \\
\hline 3.957 & 97.215 & -0.004 & 0.778 & ---- & -0.903 & ---- & 1.441 & 0.192 & 0.000 & -0.292 \\
\hline 1.369 & 98.583 & 0.278 & 0.053 & ---- & 0.229 & ---- & 0.218 & 0.984 & -0.695 & -0.725 \\
\hline 0.947 & 99.529 & -0.103 & 1.174 & ---- & 0.822 & ---- & 0.394 & 0.287 & 0.473 & -0.053 \\
\hline 0.333 & 99.862 & -0.101 & -0.290 & ---- & -0.721 & ---- & -0.143 & 0.739 & 0.589 & -0.025 \\
\hline 0.138 & 100.000 & -0.039 & 0.605 & ---- & 0.064 & ---- & -0.595 & 0.408 & -0.118 & 0.035 \\
\hline
\end{tabular}

The values ${ }^{1}$ and ${ }^{2}$ correspond to the first and second discarded variables respectively

Table 3 - Estimation of variances $(\lambda)$, accumulated variances ( $\lambda \mathrm{ac})$ and standardised weighting coefficients of the canonical variables for the characteristics, thousand seed weight (TW), mean germination time (MGT), primary root protrusion at nine days (G), normal seedlings (NS), primary root protrusion on the fifth day (PL), length of hypocotyl (HL), length of root (RL), shoot dry weight (SDW) and root dry weight (RDW) for an osmotic potential of $-0.3 \mathrm{MPa}$ in a solution of $\mathrm{NaCl}$

\begin{tabular}{rccrrrrrrrr}
\hline$\lambda$ & \multicolumn{1}{c}{$\lambda \mathrm{ac}$} & \multicolumn{1}{c}{ TW } & \multicolumn{1}{c}{ MGT } & \multicolumn{1}{c}{ G } & \multicolumn{1}{c}{ NS $^{3}$} & \multicolumn{1}{c}{$\mathrm{PL}^{1}$} & \multicolumn{1}{c}{ HL } & \multicolumn{1}{c}{ RL } & \multicolumn{1}{c}{ SDW $^{2}$} & RDW \\
\hline 70.197 & 87.669 & 1.045 & 0.175 & -0.233 & -0.486 & 0.525 & -0.159 & -0.345 & 0.331 & -0.104 \\
5.246 & 94.221 & 0.145 & 0.980 & -1.242 & 0.475 & 0.025 & 0.309 & 0.200 & -0.190 & 0.405 \\
2.134 & 96.885 & 0.053 & -0.530 & -0.937 & 0.119 & 0.950 & -0.420 & -0.356 & -0.767 & 1.115 \\
1.593 & 98.875 & -0.054 & -0.834 & 0.595 & -0.606 & -0.103 & 1.035 & 0.497 & 0.340 & 0.250 \\
0.487 & 99.483 & -0.100 & -0.028 & -0.616 & 0.890 & -0.501 & -0.292 & 0.944 & 0.290 & -0.254 \\
0.181 & 99.709 & -0.080 & 0.300 & 2.075 & -0.281 & -1.707 & -0.304 & 0.011 & 0.222 & 0.275 \\
0.138 & 99.882 & 0.063 & -0.436 & -0.635 & -0.0003 & 1.888 & -0.307 & 0.159 & -0.054 & -0.082 \\
0.085 & 99.988 & -0.066 & -0.488 & 1.032 & 1.118 & -1.402 & 0.124 & -0.350 & 0.413 & 0.056 \\
\hline
\end{tabular}


Table 3 Continued

\begin{tabular}{rrrrrrrrrrr}
\hline 0.010 & 100.000 & -0.190 & 0.339 & -1.682 & -1.252 & 2.321 & 0.095 & -0.116 & 0.708 & 0.151 \\
68.934 & 87.717 & 1.035 & 0.182 & 0.143 & -0.334 & ---- & -0.144 & -0.330 & 0.340 & -0.133 \\
5.246 & 94.392 & 0.145 & 0.981 & -1.224 & 0.481 & ---- & 0.310 & 0.201 & -0.189 & 0.403 \\
2.012 & 96.952 & 0.051 & -0.543 & -0.259 & 0.383 & ---- & -0.386 & -0.325 & -0.753 & 1.103 \\
1.592 & 98.977 & -0.055 & -0.821 & 0.530 & -0.648 & ---- & 1.046 & 0.504 & 0.360 & 0.222 \\
0.480 & 99.588 & -0.098 & -0.035 & -0.978 & 0.762 & ---- & -0.283 & 0.959 & 0.300 & -0.281 \\
0.166 & 99.798 & -0.048 & 0.127 & 1.070 & -0.515 & ---- & -0.421 & 0.138 & 0.189 & 0.189 \\
0.106 & 99.933 & 0.061 & -0.772 & 0.275 & 1.163 & ---- & -0.052 & -0.138 & 0.019 & -0.106 \\
0.052 & 100.000 & -0.213 & 0.151 & -0.072 & -0.305 & ---- & 0.178 & -0.317 & 0.826 & 0.206 \\
64.199 & 88.186 & 1.062 & 0.167 & 0.033 & -0.169 & ---- & -0.265 & -0.412 & ---- & 0.027 \\
5.151 & 95.262 & 0.111 & 1.004 & -1.168 & 0.390 & ---- & 0.402 & 0.271 & ---- & 0.289 \\
1.693 & 97.588 & -0.049 & -0.946 & 0.247 & -0.321 & ---- & 0.647 & 0.262 & ---- & 0.807 \\
1.071 & 99.058 & 0.105 & -0.202 & 0.663 & -0.577 & ---- & 0.767 & 0.236 & ---- & -0.562 \\
0.420 & 99.636 & -0.005 & -0.106 & -0.938 & 0.793 & ---- & -0.183 & 1.028 & ---- & -0.443 \\
0.159 & 99.855 & 0.002 & 0.092 & 1.031 & -0.424 & ---- & -0.447 & 0.251 & ---- & 0.112 \\
0.106 & 100.000 & 0.066 & -0.775 & 0.281 & 1.168 & ---- & -0.058 & -0.127 & ---- & -0.111 \\
63.548 & 88.862 & 1.061 & 0.156 & -0.077 & ---- & ---- & -0.295 & -0.382 & ---- & 0.006 \\
4.890 & 95.699 & 0.103 & 1.034 & -0.930 & ---- & ---- & 0.513 & 0.221 & ---- & 0.353 \\
1.643 & 97.997 & -0.058 & -1.013 & 0.054 & ---- & ---- & 0.501 & 0.290 & ---- & 0.807 \\
0.953 & 99.330 & 0.107 & -0.517 & 0.358 & ---- & ---- & 0.727 & 0.460 & ---- & -0.618 \\
0.327 & 99.787 & -0.043 & 0.378 & -0.724 & ---- & ---- & -0.299 & 0.947 & ---- & -0.253 \\
0.153 & 100.000 & 0.027 & -0.204 & 1.110 & ---- & ---- & -0.419 & 0.143 & ---- & 0.079 \\
\hline
\end{tabular}

The values ${ }^{1},{ }^{2}$ and ${ }^{3}$ correspond to the first, second and third discarded variables respectively

For the condition of $-0.6 \mathrm{MPa}$, three selection cycles were performed, with the discarded characteristics being G, MGT and RL, based on the weight of the weighting coefficients $(2.273,1.046$ and 1.100) for the last canonical variable respectively (Table 4).

Table 4 - Estimation of variances $(\lambda)$, accumulated variances ( $\lambda \mathrm{ac})$ and standardised weighting coefficients of the canonical variables for the characteristics, thousand seed weight (TW), mean germination time (MGT), primary root protrusion at nine days (G), normal seedlings (NS), primary root protrusion at five days (PL), length of hypocotyl (HL), length of root (RL), shoot dry weight (SDW) and root dry weight (RDW) for an osmotic potential of $-0.6 \mathrm{MPa}$ in a solution of $\mathrm{NaCl}$

\begin{tabular}{rcccccccccc}
\hline$\lambda$ & $\lambda \mathrm{ac}$ & \multicolumn{1}{c}{$\mathrm{TW}$} & $\mathrm{MGT}^{2}$ & \multicolumn{1}{c}{$\mathrm{G}^{1}$} & \multicolumn{1}{c}{$\mathrm{NS}$} & \multicolumn{1}{c}{$\mathrm{PL}$} & \multicolumn{1}{c}{$\mathrm{HL}$} & $\mathrm{RL}^{3}$ & \multicolumn{1}{c}{$\mathrm{SDW}$} & $\mathrm{RDW}$ \\
\hline 90.685 & 79.420 & 1.177 & -0.280 & 0.216 & -0.503 & -0.259 & -0.538 & 0.376 & 0.375 & 0.529 \\
13.878 & 91.574 & 0.136 & -0.178 & 0.608 & 1.045 & -1.065 & 0.299 & 0.115 & -0.599 & 0.417 \\
4.203 & 95.255 & 0.097 & -0.233 & 0.676 & 0.058 & 0.262 & -0.567 & 0.337 & -0.485 & 0.464 \\
2.458 & 97.408 & -0.195 & -0.023 & -0.293 & -0.860 & 0.452 & 0.007 & 0.363 & 1.261 & -0.078 \\
1.475 & 98.700 & -0.024 & 0.024 & -0.234 & 0.713 & 0.201 & -0.486 & 0.193 & 1.181 & -1.701 \\
1.086 & 99.651 & 0.078 & 0.346 & -0.112 & 0.016 & 0.523 & 0.783 & -0.069 & 0.371 & -0.735 \\
0.206 & 99.831 & -0.059 & -1.242 & 2.101 & -0.321 & -2.119 & -0.010 & 0.186 & 0.437 & -0.576 \\
0.160 & 99.971 & 0.006 & 0.603 & -0.605 & 0.127 & 0.600 & -0.535 & 1.144 & -0.787 & 0.206 \\
\hline
\end{tabular}


Table 4 Continued

\begin{tabular}{rrrrrrrrrrr}
\hline 0.033 & 100.000 & -0.009 & 0.056 & 2.273 & 0.107 & -2.208 & -0.121 & -0.006 & 0.072 & -0.095 \\
90.302 & 79.897 & 1.173 & -0.218 & ---- & -0.509 & -0.049 & -0.534 & 0.378 & 0.372 & 0.536 \\
13.421 & 91.772 & 0.135 & -0.002 & ---- & 1.044 & -0.501 & 0.320 & 0.123 & -0.604 & 0.441 \\
4.026 & 95.334 & 0.099 & -0.037 & ---- & 0.083 & 0.913 & -0.555 & 0.373 & -0.495 & 0.512 \\
2.437 & 97.491 & -0.202 & -0.109 & ---- & -0.890 & 0.136 & 0.026 & 0.338 & 1.297 & -0.107 \\
1.468 & 98.789 & -0.032 & -0.051 & ---- & 0.686 & -0.039 & -0.486 & 0.186 & 1.230 & -1.734 \\
1.084 & 99.749 & 0.075 & 0.310 & ---- & 0.012 & 0.409 & 0.781 & -0.071 & 0.402 & -0.767 \\
0.165 & 99.895 & -0.017 & 0.035 & ---- & -0.029 & -0.020 & -0.473 & 1.111 & -0.549 & -0.029 \\
0.119 & 100.000 & 0.032 & 1.046 & ---- & 0.321 & 0.052 & -0.277 & 0.314 & -0.510 & 0.361 \\
86.905 & 79.439 & 1.164 & ---- & ---- & -0.429 & -0.025 & -0.527 & 0.420 & 0.257 & 0.564 \\
13.421 & 91.707 & 0.135 & ---- & ---- & 1.045 & -0.501 & 0.320 & 0.123 & -0.605 & 0.442 \\
4.022 & 95.383 & 0.102 & ---- & ---- & 0.098 & 0.918 & -0.554 & 0.380 & -0.519 & 0.519 \\
2.415 & 97.591 & -0.193 & ---- & ---- & -0.863 & 0.163 & 0.038 & 0.365 & 1.246 & -0.088 \\
1.465 & 98.930 & -0.028 & ---- & ---- & 0.693 & -0.020 & -0.466 & 0.199 & 1.231 & -1.748 \\
1.005 & 99.849 & 0.067 & ---- & ---- & -0.083 & 0.373 & 0.846 & -0.183 & 0.481 & -0.791 \\
0.165 & 100.000 & -0.018 & ---- & ---- & -0.040 & -0.021 & -0.462 & 1.100 & -0.532 & -0.042 \\
78.236 & 78.363 & 1.116 & ---- & ---- & -0.402 & -0.088 & -0.269 & ---- & 0.307 & 0.539 \\
13.298 & 91.682 & 0.147 & ---- & ---- & 1.053 & -0.534 & 0.396 & ---- & -0.590 & 0.445 \\
3.714 & 95.402 & 0.154 & ---- & ---- & 0.245 & 0.852 & -0.345 & ---- & -0.694 & 0.602 \\
2.192 & 97.598 & -0.147 & ---- & ---- & -0.886 & 0.298 & 0.259 & ---- & 1.106 & 0.199 \\
1.419 & 99.019 & -0.028 & ---- & ---- & 0.606 & 0.065 & -0.291 & ---- & 1.434 & -1.756 \\
0.979 & 100.000 & 0.068 & ---- & --- & -0.101 & 0.341 & 0.775 & ---- & 0.263 & -0.688 \\
\hline
\end{tabular}

The values ${ }^{1},{ }^{2}$ and ${ }^{3}$ correspond to the first, second and third discarded variables respectively

The effect of multicollinearity on clustering in the bean hinders the true formation of groups (CARGNELUTTI FILHO et al., 2009), the effect being more expressive under salt stress $(-0.3$ and -0.6 MPa). Grouping of the bean genotypes by the Tocher optimisation method differed only under conditions of severe and weak multicollinearity. However, under non-stress conditions, multicollinearity did not change the grouping (Table 5); this can be explained by the lower number of discard cycles required to reduce the multicollinearity, due to the weaker relationship between the evaluated characteristics (Table 1).

Table 5 - Clustering before discarding variables (nine characteristics for all potentials), and after discarding variables (seven characteristics for the potential of $0,0 \mathrm{MPa}$, and six characteristics for the potentials of -0.3 and $-0.6 \mathrm{MPa}$ ) based on morphological characteristics, by the Tocher optimisation method, in 13 bean genotypes during seed germination under osmotic potentials of $0.0,-0.3$ and $-0.6 \mathrm{MPa}$ in a solution of $\mathrm{NaCl}$

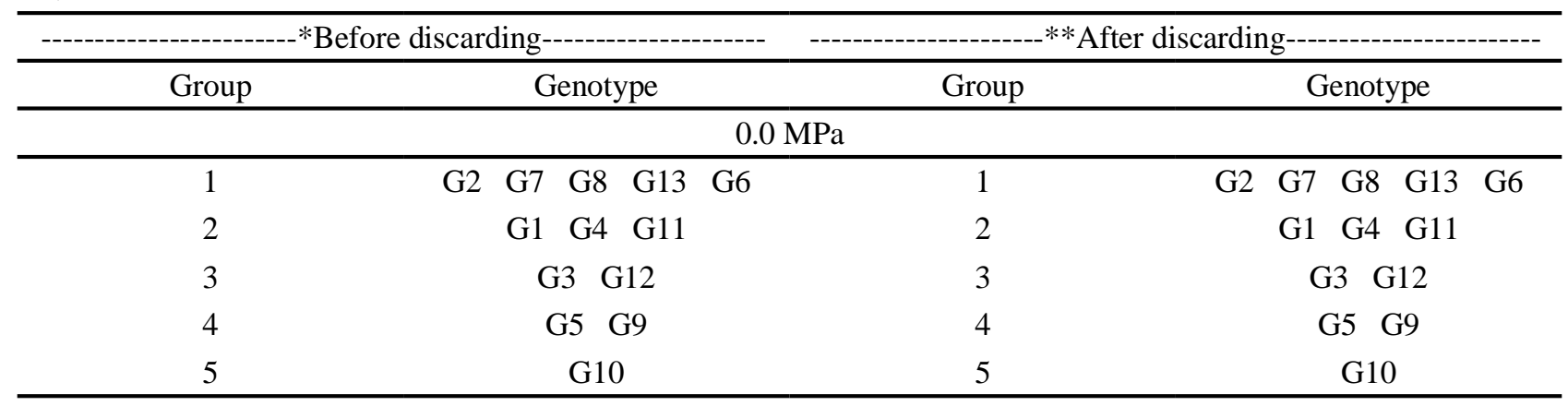


Table 5 Continued

\begin{tabular}{|c|c|c|c|c|c|}
\hline \multicolumn{6}{|c|}{$-0.3 \mathrm{MPa}$} \\
\hline 1 & \multicolumn{2}{|r|}{$\begin{array}{llll}\text { G2 } & \text { G8 } & \text { G13 } & \text { G6 }\end{array}$} & 1 & & $\begin{array}{lll}\text { G2 } & \text { G8 } & \text { G7 }\end{array}$ \\
\hline 2 & \multicolumn{2}{|r|}{ G1 G4 G10 } & 2 & & G6 G13 \\
\hline 3 & \multicolumn{2}{|r|}{ G3 G12 } & 3 & & G1 G4 \\
\hline 4 & \multicolumn{2}{|r|}{ G5 } & 4 & & G9 G12 \\
\hline 5 & \multicolumn{2}{|r|}{ G9 } & 5 & & G3 G5 \\
\hline 6 & \multicolumn{2}{|r|}{ G7 } & 6 & & G11 \\
\hline 7 & \multicolumn{2}{|r|}{ G11 } & 7 & & G10 \\
\hline \multicolumn{6}{|c|}{$-0.6 \mathrm{MPa}$} \\
\hline 1 & & $\begin{array}{llll}\text { G9 } & \text { G5 } & \text { G6 } & \text { G13 }\end{array}$ & 1 & G3 & $\begin{array}{cccc}\text { G9 } & \text { G5 } & \text { G6 } & \text { G13 } \\
& \text { G8 } & & \end{array}$ \\
\hline 2 & & G1 G4 & 2 & & G1 G4 G11 \\
\hline 3 & & G8 G11 & 3 & & G7 G10 \\
\hline 4 & & G7 G10 & 4 & & G2 \\
\hline 5 & & G2 & 5 & & G12 \\
\hline 6 & & G12 & & & \\
\hline
\end{tabular}

*Presence of severe multicollinearity. The osmotic potential under study displayed the characteristics: TW; MGT; G; NS; PL; HL; RL; SDW; RDW; ** Presence of weak multicollinearity. The characteristics maintained were: for the osmotic potential of 0,0 MPa: TW, MGT, NS, HL, RL, SDW and RDW; for the osmotic potential of -0,3 MPa: TW, MGT, G, HL, RL and RDW; and for the osmotic potential of -0,6 MPa: TW, NS, PL, HL, SDW and RDW

For the osmotic potentials of $0.0,-0.3$ and $-0.6 \mathrm{MPa}$, five, seven and five groups were formed respectively in the absence of multicollinearity (Table 5). Results obtained for the different osmotic potentials reinforce the idea of the need to study the clustering of genotypes for a wide range of saline environments. According to Almeida et al. (2011), similar results to those obtained in this study were found, where the grouping of genotypes of Vigna unguiculata was altered during plant development in different saline environments, due to the phenotypic responses varying greatly from one environment to another.

The genotype pairs, G1 and G4, and G6 and G13, remained together for all osmotic potentials (with and without multicollinearity), showing them to be the least dissimilar genotypes (Table 5). Those genotypes that formed groups with a high index of dissimilarity can be evaluated as promising parents in artificial crosses to obtain segregating populations and identify transgressive genotypes (BERTINI et al., 2010).

\section{CONCLUSIONS}

1. The method of discarding variables using canonical variables is effective in reducing multicollinearity, with the number of discarded descriptors of physiological quality being higher for potentials of -0.3 and $-0.6 \mathrm{MPa}$;
2. The clustering of common bean genotypes is modified under conditions of severe and weak multicollinearity, but only under conditions of salt stress.

\section{ACKNOWLEDGEMENTS}

The authors wish to thank the Coordination for the Training of Personnel in Higher Education (CAPES/ REUNI), the National Council for Scientific and Technological Development (CNPq), and the Research Support Foundation of Espírito Santo (FAPES) for their encouragement and scholarships granted. The authors also thank the Agronomic Institute of Paraná (IAPAR) for the supply of seeds.

\section{REFERENCES}

ALMEIDA, W. S. et al. Identificação de genótipos de feijãocaupi tolerantes a salinidade avaliado por meio de método multivariado. Ciência Rural, v. 41, n. 11, p. 1884-1889, 2011.

ANDRÉO-SOUZA, Y. et al. Efeito da salinidade na germinação de sementes e no crescimento inicial de mudas de pinhão-manso. Revista Brasileira de Sementes, v. 32, n. 2, p. 83-92, 2010.

AYDIN, A.; KANT, C.; TURAN, M. Humic acid application alleviate salinity stress of bean (Phaseolus vulgaris L.) 
plants decreasing membrane leakage. African Journal of Agricultural Research, v. 7, n. 7, p. 1073-1086, 2012.

BAYUELO-JIMENEZ, J. S.; JASSO-PLATA, N.; OCHOA, I. Growth and physiological responses of Phaseolus species to salinity stress. International Journal of Agronomy, v. 2012, p. 1-13, 2012.

BEN-GAL, A. et al. Is osmotic potential a more appropriate property than electrical conductivity for evaluating wholeplant response to salinity? Environmental and Experimental Botany, v. 65, n. 2, p. 232-237, 2009.

BERTINI, C. H. C. M. et al. Análise multivariada e índice de seleção na identificação de genótipos superiores de feijão-caupi. Acta Scientiarum. Agronomy, v. 32, n. 4, p. 613-619, 2010.

BOURGAULT, M. et al. Effects of deficit irrigation and salinity stress on common bean (Phaseolus Vulgaris L.) and mungbean (Vigna Radiata) wilczek grown in a controlled environment. Journal of Agronomy and Crop Science, v. 196, n. 4, p. $262-$ $272,2010$.

BRASIL. Ministério daAgricultura, Pecuáriae Abastecimento. Secretaria Nacional de Defesa Agropecuária. Regras para análise de sementes. Brasília, DF: MAPA : SNDA, 2009. $395 \mathrm{p}$.

CARGNELUTTI FILHO, A. et al. Agrupamento de cultivares de feijão em presença e em ausência de multicolinearidade. Ciência Rural, v. 39, n. 9, p. 2409-2418, 2009.

COELHO, D. L. M. et al. Estresse hídrico com diferentes osmóticos em sementes de feijão e expressão diferencial de proteínas durante a germinação. Acta Scientiarum. Agronomy, v. 32, n. 3, p. 491-499, 2010.

COMPANHIA NACIONAL DE ABASTECIMENTO. Acompanhamento da safra brasileira: grãos: safra 2014/15. Brasília, DF: CONAB, 2015. v. 2, n. 5, 116 p.

CRUZ, C. D. GENES-a software package for analysis in experimental statistics and quantitative genetics. Acta Scientiarum. Agronomy, v. 35, n. 3, p. 271-276, 2013.

CRUZ, C. D.; REGAZZI, A. J. Modelos biométricos aplicados ao melhoramento genético. 2. ed. rev.. Viçosa, MG: UFV, 2001. 390 p.

CRUZ, C. D.; REGAZZI, A. J; CARNEIRO, P. C. S. Modelos biométricos aplicados ao melhoramento genético. 4. ed. Viçosa,MG: UFV, 2012. 514 p.

FOOD AND AGRICULTURE ORGANIZATION, 2013. Disponível em: <http://faostat3.fao.org/faostat-gateway/go/to/ download/Q/QC/E>. Acesso em: 04 ago. 2014.

HADŽIĆ, A. et al. Energy and nutritional value of raw grains of domestic bean varieties. Agroznanje, v. 14, n. 1, p. 51-58, 2013.
HERNÁNDEZ-LUCERO, E. et al. Differential expression of genes for tolerance to salt stress in common bean (Phaseolus vulgaris L.). Plant molecular biology reporter, v. 32, n. 2, p. 318-327, 2014.

JOST, E. et al. Efeitos gênicos do teor de cálcio em grãos de feijão. Ciência Rural, v. 39, n. 1, p. 31-37, 2009.

KHADRI, M.; TEJERA, N. A.; LLUCH, C. Sodium chlorideABA interaction in two common bean (Phaseolus vulgaris) cultivars differing in salinity tolerance. Environmental and Experimental Botany, v. 60, n. 2, p. 211-218, 2007.

LABOURIAU, L. G. A germinação de sementes. Washington: OEA, 1983. 174 p.

MACHADO, R. et al. Efeito da salinidade em características físico-hídricas em solos salino-sodilizados no perímetro irrigado Jabiberi-SE. Revista Brasileira de Agricultura Irrigada, v. 1, n. 1, p. 15-19, 2007.

MESQUITA, J. B.; MARINO, R. H. Micoflora de sementes de feijão comum (Phaseolus vulgaris L.) provenientes do Estado de Sergipe. Revista Brasileira de Ciências Agrárias, v. 4 , n. 3, p. 252-256, 2009.

MONTGOMERY, D. C.; PECK, E. A. Introduction to linear regression analysis. New York: J. Wiley, 1981. 504 p.

PEDROSA, M. M. et al. Effects of industrial canning on the proximate composition, bioactive compounds contents and nutritional profile of two Spanish common dry beans (Phaseolus vulgaris L.). Food Chemistry, v. 166, p. 68-75, 2015.

PIMENTA, J. A. Relações hídricas. In: KERBAUY, G. B. (Ed.). Rio de Janeiro: Guanabara Koogan, 2004. cap. 1, p. $1-39$

PLANS, M. et al. Characterization of common beans (Phaseolus vulgaris L.) by infrared spectroscopy: comparison of MIR, FTNIR and dispersive NIR using portable and benchtop instruments. Food Research International, v. 54, n. 2, p. 1643-1651, 2013.

RENCHER, A. C. Methods of multivariate analysis. Hoboken, NJ: John Wiley and Sons, 2003.738 p.

ROSA, S. S. et al. Potential for increasing the zinc content in common bean using genetic improvement. Euphytica, v. 175, n. 2, p. 207-213, 2010.

ROSALES, M. A. et al. Physiological analysis of common bean (Phaseolus vulgaris L.) cultivars uncovers characteristics related to terminal drought resistance. Plant physiology and biochemistry, v. 56, p. 24-34, 2012.

SAEIDI-SAR, S. et al. Effects of ascorbic acid and gibberellin $\mathrm{GA}_{3}$ on alleviation of salt stress in common bean (Phaseolus vulgaris L.) seedlings. Acta Physiologiae Plantarum, v. 35, n. 3, p. 667-677, 2013. 